Article

\title{
Backlash or Widening the Gap?: Women's Reproductive Rights in the Twenty-First Century
}

\author{
Dorota Anna Gozdecka ${ }^{\dagger}$ \\ Faculty of Law, University of Helsinki, 00014 Helsinki, Finland; dorota.gozdecka@helsinki.fi \\ † The author would like to thank Professor Margaret Thornton and two anonymous reviewers whose comments \\ have been invaluable in the process of revising this article.
}

Academic Editor: Margaret Thornton

Received: 15 November 2019; Accepted: 7 February 2020; Published: 20 February 2020

check for updates

\begin{abstract}
This article examines legal challenges to women's reproductive rights in Ireland and the United States, arguing that backlash against reproductive rights is a consequence of the long unsettled position of women's reproductive freedom in liberal democracies and the catalogue of rights. It examines the legal foundations of reproductive rights and their perceived conflicts with other values, such as religion, and focuses on the current legal challenges to women's bodily autonomy regarding choice and motherhood. It demonstrates the many contexts in which women have not acquired full reproductive freedom, and explores the nature of the current backlash. It argues that the nature of the backlash is not simply a reclamation of what has been legally guaranteed, but instead a deepening of the preexisting divides within reproductive justice globally.
\end{abstract}

Keywords: reproductive rights; access to abortion; global gag rule; populism

\section{Introduction}

The topic of women's reproductive freedom entered feminist theory discourse in the 1960s (Siegel 2007), though arguments for women's reproductive freedom have been historically present in discussions on women's liberation since the mid-1800s (Caron 2008). Since the adoption of the Convention on the Elimination of all Forms of Discrimination Against Women (CEDAW) and the subsequent upholding of the importance of women's rights in the Beijing Platform for Action (United Nations 1995), women's reproductive freedom has been intrinsically linked with the notion of human rights, which have since been thought to include women's reproductive rights (Cumberland 2012).

Women's reproductive rights have quickly become the cornerstone of a feminist approach to human rights law and have been unequivocally supported by the vast majority of feminist legal scholars in diverse contexts (Hooton 2005; Labbok et al. 2008; Smyth 2002; Peters and Wolper 2018). It is thus with great dismay that current feminist theory approaches the rapidly evolving legal changes to women's reproductive freedoms. Current challenges to long-fought-for legal guarantees, such as those encapsulated in the Roe $v$ Wade $^{1}$ judgment concerning access to abortion, are seen as a backlash and a fundamental turn in the approach to women's rights. Feminists struggle to classify current developments, which are seen as the return of traditional conservative narratives (Franklin and Ginsburg 2019), as well as an attack on women's rights more generally (Starrs 2017).

In this article I will examine historical and current legal challenges to women's reproductive rights in Europe and the United States and argue that these developments are not in fact a surprise, but rather a consequence of the long unsettled position of women's reproductive rights in Western

$1 \quad$ Roe v. Wade, 410 U.S. 113. 1973. 
liberal democracies. Following and reevaluating the findings of previous work on selected aspects of this problem (Gozdecka 2009; Gozdecka 2012; Gozdecka 2015b; Gozdecka 2015a), I assert that women's reproductive rights have never truly found a comfortable spot in the catalogue of women's rights, and that what is seen as a backlash is an exploitation of the ambiguous approach to women's reproductive freedom.

I will begin by examining the history of reproductive rights and their perceived conflicts with other values, such as religion, then focus on the current legal challenges to women's ability to decide on whether they wish to become mothers. Finally, I will demonstrate how these challenges reflect the ambivalent commitment of liberal democracies to women's reproductive freedom. My key argument will show that in many contexts, women have never fully acquired unfettered reproductive freedom. While the perception of backlash is not entirely unfounded, the true nature of this "backlash" is not a simple taking back of what has been legally guaranteed, but instead an exploitation of vulnerabilities in the current legal systems and a deepening of the gaps in the access to reproductive justice. The article will demonstrate that much remains to be accomplished insofar as women's access to reproductive rights globally.

\section{Influences on Women's Reproductive Rights and the Notion of Backlash}

Reproductive rights have long been a subject of debate. Feminist scholars have argued that without the right to reproductive choice, all other economic or social rights have only limited power to advance the wellbeing of women (Freedman and Isaacs 1993). Others have seen the focus on reproduction and motherhood more generally as a social construct reinforcing a patriarchal conception of womanhood (Fineman 1995). While many scholars anticipated gradual advancement of reproductive rights globally (Reichenbach and Roseman 2011), the twenty-first century instead brought about the state of the perceived "backlash". As I will show below, liberal democracies have not, however, been overly welcoming to the idea of women's reproductive rights in the first place. The "backlash" we are currently experiencing is thus in my understanding not as much a simple reversal of already achieved progress, but instead an exploitation of the uncertainties regarding the state of women's reproductive rights in Western democracies. Legal challenges exploiting these uncertainties attempt to make access to reproductive justice more difficult, and additional legislative obstacles brought by "backlash" legislation and judicial decisions impact the most vulnerable women the most (Ross and Solinger 2017). Such changes are particularly visible in countries with strongly mobilized religious populations that are experiencing, or have previously experienced, conservative political leadership.

The nexus between conservatism, traditional religious views and reproductive rights isn't surprising as, since reproductive rights include prevention of, assistance with, or termination of pregnancy, many see it as overlapping with the protection of the fetus (a potential life). Such protection coincides with the core beliefs of many institutionalized religions, including both Catholicism and Evangelism. As I mentioned in my earlier work (Gozdecka 2012), the focus on the role of God in the process of human creation in many beliefs is a ground for the inclusion of religiously motivated views in many discussions regarding women's reproductive rights. When religious groups take on the position of 'defenders' of their religious values, they present themselves as legitimate entities with an interest in taking political action (Wald et al. 2005), and their beliefs are transferred from their private religious spheres into public political forces (Wald et al. 1988). The process of politicization of religion favors political homogeneity over the individual religious beliefs of members of various congregations (Ibid), which often allows politicized religious beliefs to become militant in their attempts to influence women's reproductive freedoms. While I have argued that this politicization of religious group identities in diverse societies is more perceptible in societies where religious identity is more homogenous (Gozdecka 2012), the twenty-first century has challenged this assumption and brought an unprecedented return of traditional religious arguments in political discourse in many Western societies. Instead of the expected pluralization of religious discourses, the twenty-first century has shown an increased prevalence of discourse on religious values, even in relatively multicultural 
societies like Australia, Canada or New Zealand (Ahdar 2017; Malloy 2017). This has happened not only in the context of women's rights, but also in debates on same-sex marriage, which has been perceived by religious groups as a danger to traditional family norms, just as reproductive rights have (Small 2018). To be sure, the simple juxtaposition of all religious and women's rights (Okin 1999) has been demonstrated as lacking nuance (Al-Hibri 1999; Bano 2016) and the construction of a conflict between the two has been more frequent in relation to minority or new religions (Gozdecka 2015b; Bano 2016). As Bano observed, while new or minority religions have been condemned for their religious conservatism, Western liberal theory often ignores Western cultural and religious influences, framing them as neutral rather than religious (Bano 2016, p. 163). Pigeonholing conservatism as synonymous with only some religions, in particular Islam, turned out to be overly simplistic and the twenty-first century has challenged these assumptions by reanimating the troubled relationship between traditionally dominant religions and women's reproductive rights (Andaya 2019; Morgan 2019). Once nearly forgotten as 'neutral,' strong religious sentiment in Western democracies has been revived and has increasingly been combined with nationalism, reinvigorating the discourse on reproducing the nation with all its gendered and cultural order (Yuval-Davis 1996). In this era of growing far right populism and nationalism, the return of politicized religious nationalisms and their impact on women's reproductive freedom seems to be a consequence of the frequent appeal to tradition, national values, and the merging of nationalism with traditionalist religious values. As Friedland observes in his political analysis of religious nationalisms:

Religious nationalisms are animated by family drama; they all center their fierce energies on the family, its erotic energies, its gendered order. This is because the institutional logic of religion centers on the order of creation, locating humanness in the cosmos, replicating cosmology through ritual, a practical metaphysics that necessarily points before life and death. (Friedland 2001, p. 134)

As Himmelstein adds, a common theme in the religious conservatism that opposes women's reproductive autonomy is a general opposition to the perceived excesses of freedom and autonomy, as well as the liberation from traditional roles and norms (Himmelstein 1986, p. 9). Elomäki and Kantola note that impact of conservatism in many countries cannot be underestimated when it comes to promoting traditional views on gender and family and increasing anti-feminist discourses (Elomäki and Kantola 2018, p. 338). While we attribute the adjectives 'religious' or 'conservative' to approaches to women's rights in those religions that have seemed culturally alien (Gozdecka 2015b; Bano 2016), the impact of our own cultural and national approaches on reproductive freedom has often remained understudied. Yet feminist scholars in Ireland, the US, and other seemingly human rights-oriented places have pointed out that the situation has always been that of a struggle (e.g., Rohlinger and Grace 2018). Many liberal democracies have struggled with securing reproductive freedom goals as well as securing reproductive justice for those who are excluded on account of race (Smith 2005) or economic status (Chrisler 2014; Roberts 2015). The nature of the current backlash is a widening of the chasms between ambitious reproductive justice goals and legal reality. In the following section, I will illustrate that the perception of a Western commitment to reproductive rights is historically misleading, given that the majority of binding human rights instruments steer clear of mentioning reproductive rights altogether. Furthermore, I will focus on the current perception of said backlash and demonstrate that the nature of this backlash is complex and leads primarily to the deepening of the existing gaps. The nature of the backlash thus does not necessarily reverse what has been legally set in stone, but further widens the gap between the goals and material reality by obstructing access to reproductive health services for those women who need it the most.

\section{International and Domestic Approaches to Reproductive Rights: Historical Battle for the Right to Abortion in Ireland and the United States}

While many have seen reproductive rights as gradually more entrenched in law and human rights law more specifically (Cottingham et al. 2010; Reichenbach and Roseman 2011), the legal standards in this arena have been at best vague and ambiguous. Historically, the strongest legal grounds for securing 
international reproductive freedom are included in the Convention on the Elimination of All Forms of Discrimination Against Women (CEDAW 1979), which explicitly includes provisions on reproductive rights. CEDAW challenges traditional family patterns by introducing the legal obligation to assure equality of men and women in all aspects of life, including family planning. In Article 16, CEDAW stipulates explicitly that women ought to have not only the possibility, but also equality, in deciding on the number and spacing of their children, and in Article 10 it guarantees access to the information, education and means to enable the exercise of these rights. Yet, despite the progressiveness of CEDAW, or perhaps because of it, it quickly became the human rights convention with the highest number of reservations (Riddle 2002). This amount of reservations is ironically the consequence of none other than the inclusion of women's reproductive rights. Due to these reservations, the gap between the strong conceptual commitment expressed in CEDAW and its implementation remains vast in many countries across the globe.

Other international declarations and legal standards keep references to reproductive rights sparse or aspirational. The frequently cited commitments to the idea of reproductive rights reaffirmed during the world summits in Cairo in 1994 and Beijing in 1995 remain aspirational but non-binding. The goal of 'explicit recognition and reaffirmation of the right of all women to control all aspects of their health, in particular their own fertility, is basic to their empowerment' (United Nations 1995, p. 17) remains mostly unfulfilled, with the exception of several countries, mainly in Northern Europe, that have often been seen as positive models for other places (e.g., Lottes 2002).

Yet, even Europe, the seemingly progressive continent with regards to women's rights, has avoided a strong commitment to reproductive rights in EU fundamental rights or human rights (Gozdecka 2015b). The European Union's most detailed document on the matter, the now aged Van Lancker report from 2002 (European Parliament 2002), considering all relevant international documents and actions on reproductive rights. In its conclusion, it admits stark discrepancies in sexual and reproductive health and rights within the EU and acknowledges the gaps between these aspirations and reality. The necessity of further commitment to reproductive rights was reaffirmed by the European Union in the European Parliament's resolution on the status of fundamental rights in the European Union in Resolution 2007 (2145). The resolution included a mention of reproductive rights and recommended withdrawing Member States' reservations to CEDAW as well as assuring that women can fully enjoy reproductive rights, access to contraception, and avoid high-risk illegal abortions. As far as the main human rights law legislator in the European region, the Council of Europe (COE), is concerned, the situation has not been much better. The sparse documents on the topic include soft law sources such as Resolution 1399 (Parliamentary Assembly of the Council of Europe 2004b) and Recommendation 1675 (Parliamentary Assembly of the Council of Europe 2004a), concerning reproductive rights and a Report (Parliamentary Assembly of the Council of Europe 2008a) and Resolution 1607 (Parliamentary Assembly of the Council of Europe 2008b) on decriminalizing abortion. Similar to the EU's reports, the COE's documents have noted the enormous disparity of standards between Member States in matters of reproductive health. The aspirations included in the soft law have often remained unfulfilled and the most recent sources have expressed a deep concern over the appearance of multiple regressive measures in this area (Mijatovic 2019) on the continent.

Due to rather sparse international and regional commitment, the gap between the aspirations of giving every woman a right to decide about the spacing and number of her children and the reality has remained vast globally, including in some Western democracies. The frequently compared context of the United States and Ireland (e.g., Rohlinger and Meyer 2005) shows that historically, the full recognition of women's autonomy has been particularly problematic when it comes to abortion access. Human rights standards have not contributed much when it comes to women's autonomy to decide about becoming mothers in either of these countries. Despite Irish ratification of CEDAW and the European Convention on Human Rights (ECHR) and regardless of the lack of the ratification of CEDAW in the US, both Ireland and the US have followed historically similar paths when it comes to regulating abortion. Starting with the initial prohibition of abortion, these countries have only 
recently gone in very different directions in this regard, but historically they had both experienced the influence of politicized religious arguments in abortion debates. Throughout the twentieth century, the recognition of a woman's right to abortion has been oscillating between decisions signaling greater recognition of women's autonomy, and subsequent legislative and judicial backlash in response.

In Ireland the historical ban on abortion was entwined with the privileging of Catholicism prior to the amendment to the Constitution in 1973 (Gozdecka 2015b). With the privileging of Catholic natural law's interpretation of rights in many matters concerning sexuality and private life, it is unsurprising that abortion has always been illegal in Ireland. This illegality became strongly legally entrenched with the passing of the Eighth Amendment to the Constitution in 1983, when the life of the unborn became a right defended by the state (De Londras and Enright 2018). Similarly, the access to safe abortion has been seen as a continuous challenge to women's reproductive rights in the United States. As Mohr observes, abortion before quickening, or before the first foetal movement, was not uncommon in the early 1800s and abortion post-quickening was regulated by common law and treated as a criminal offence (Mohr 1979, pp. 3-4). The first wave of anti-abortion legislation between 1821 and 1841 began when Connecticut passed a bill outlawing abortion in 1821 (Greenhouse and Siegel 2011, p. 2034). While the law was a part of a broader legal framework, it was the first measure of this kind (Mohr 1979, p. 21). Eventually, during the first and second wave of anti-abortion laws, most states followed with similar measures, albeit embodied in different types of legislation (Mohr 1979, pp. 20-45, 147-70). After the establishment of the American Medical Association (AMA) in 1847, physicians affiliated with the AMA launched 'an aggressive campaign against abortion on the eve of the Civil War' (Mohr 1979 , p. 147) led by a prominent anti-abortion crusader, Dr Horatio Storer, who promoted his father's view that life begins at conception (Ehrlich and Doan 2019, p. 3). Additional support for anti-abortion legislation came from anti-vice crusaders (Mohr 1979, p. 196) who 'turned to law as part of a battle against illicit sex. In the quest to protect American youth, these activists championed laws prohibiting devices, information and preparations designed to end pregnancy.' (Ziegler 2015, p. 2). However, it was the crucial endorsement of the anti-abortion stance by the AMA that led every state to eventually ban access to abortion by the 1880s (Greenhouse and Siegel 2011, p. 2035).

Gradually, women in both countries have challenged the strict abortion bans. In Ireland, the most contentious cases found their way to the highest court and eventually brought modifications to the strict interpretation of the constitutional provision introduced by the 8th amendment. Most significantly, the $X$ case $^{2}$ of 1992 has allowed for termination in rare cases of real, imminent and substantial risk to the life of the mother, including the risk of death by 'self-destruction', which could be avoided by terminating the pregnancy (Gozdecka 2015b). Further cases such as the $C$ case $^{3}$ also gradually removed some of the restrictions of travelling for an abortion (Gozdecka 2009).

Meanwhile in the US, the early twentieth century witnessed the emergence of a family planning movement and population control movements, which kept evolving slowly from the 1920s through the 1960s (Ziegler 2015, pp. 3-4). The movements argued for improved access to contraception and abortion. With the influence of the sexual revolution in the 1960s, women's feminist movements also gained ground to gradually demand improved access to contraception and eventually to abortion (Ziegler 2013, pp. 17-18). Despite different approaches to the issue expressed firstly by population control movements and later by feminist movements, they both had had an influence on the later crystallization of the fight over access to safe abortion in the early 1970s (Ziegler 2015; Ziegler 2018). Naturally, the postulates of pro-choice movements did not remain without opposition from pro-life movements, which mobilized strongly around that time, despite having sprung up much earlier in response to the repeal of some states' anti-abortion laws (Greenhouse and Siegel 2011, p. 2047). After

Attorney General v X. 1992. IESC 1; [1992] 1 IR, Ireland.

A. and B. v EHB and C. 1997. IEHC 176. 
two cases concerning access to contraception (Griswold $v$ Connecticut ${ }^{4}$, Eisenstadt $v$ Baird ${ }^{5}$ ), access to abortion became a major decision before the Supreme Court in Roe v Wade in 1973. In Roe v Wade, the Supreme Court weighed the interest of protecting the fetus against a woman's right to privacy in her decision to undergo abortion. Reaffirming the decisions regarding the right to privacy established in both Eisenstadt and Griswold, the Supreme Court decided that the right to access abortion falls under the scope of said right (Pohlman 2005; Ziegler 2015), establishing the core of the current legal framework regulating access to abortion.

Yet as Ziegler emphasized, it would be a mistake to see Roe $v$ Wade as a simple 'right to abortion' (Ziegler 2014, p. 296). While it has most commonly been understood as 'anchored to a concept of personal autonomy derived from the due process guarantee' (Ginsburg 1985, p. 381), the Supreme Court justices, in their decision, made only seeking access to abortion a part of the 'right to privacy'. While most commonly Roe has been read as protecting women's autonomy in the decision to undergo abortion, the decision has in fact emphasized the role of a physician in the process, and made it contingent on how far along the pregnancy was (Ziegler 2014, p. 296; Gibson 2008). Greenhouse reminds us that, "Anyone reading the majority opinion in Roe $v$ Wade (...) will be struck by the physician-centric framework that the Court establishes for the exercise of the right to abortion that it is declaring. The decision vindicates the right of the physician to administer medical treatment according to his professional judgment," (Greenhouse 2009, p. 1339). Gibson adds, analyzing Justice Blackmun's extensive emphasis on medicine:

Considering that the Court's decision in Roe $v$ Wade connotes, to many, a turning point in the fight for women's equality, one might expect the Court's narrative of advancement to focus on new thinking about the rights and autonomy of women. However, Blackmun grounds the right to reproductive choice squarely within a narrative of medical progress, suggesting that women's reproductive freedom hinges on contemporary medical knowledge and technology. (Gibson 2008, p. 319)

Others highlighted that much remained to be done to secure realistic access of women to abortion (Stearns 1988). While without a doubt a major achievement for women, even Roe did not fully encapsulate the autonomy of a woman to decide whether to continue a pregnancy. The physician-centered wording, while to many not problematic, was laden with potential for divergent interpretations. Already, Justice Ginsburg noted in her 1985 article when commenting on legal developments following Roe that:

If the Court had acknowledged a woman's equality aspect, not simply a patient-physician autonomy constitutional dimension to the abortion issue, a majority perhaps might have seen the public assistance cases as instances in which, borrowing a phrase from Justice Stevens, the sovereign had violated its "duty to govern impartially". (Ginsburg 1985, p. 385)

The fight for recognizing the analogous right to privacy in terms of access to abortion has also continued in Ireland before the European Courts-both the European Court of Human Rights (ECtHR) and the European Court of Justice (ECJ) - in the hope of securing the right to abortion as a part of the right to privacy. Despite the challenges brought by the Grogan ${ }^{6}$ and Open Door ${ }^{7}$ cases, such recognition did not follow and the judgments merely recognized the right to spread information about abortion services as a free market principle and subsequently as a part of the right to freedom of expression (Gozdecka 2009; Gozdecka 2015b). In both instances though, the courts abstained from interfering with the state's general regulation of abortion and did not consider whether access to abortion was a right in itself.

\footnotetext{
Griswold v. Connecticut 381 U.S. 479. 1965.

Eisenstadt v. Baird, 405 U.S. 438 (1972).

The Society for the Protection of Unborn Children Ireland Ltd Stephen Grogan and others. 1991. Case C-159/90.

Open Door and Dublin Well Woman v. Ireland, 1992, 64/1991/316/387-388. Strasbourg: European Court of Human Rights.
} 
The fight for and against access to abortion has not settled in either of these countries, and has instead provided a catalyst for the mobilization of both pro-choice and pro-life movements. While pro-life movements did not appear as a result of Roe, the judgment provided an impulse for their consolidation nearly immediately after the decision was handed down (Ziegler 2015). From plans for constitutional reform to arguments of judicial activism, the pro-life movement has been steadily mounting challenges to the findings of Roe using both arguments of faith (Borgmann 2008) and later broader arguments, such as abortion regret interwoven into the discourse of 'pro-woman' concerns (Rose 2011), which appeared in the case of Gonzales $v$ Carhart ${ }^{8}$. At first though, challenges included Medicaid abortion funding restrictions, beginning with the Hyde Amendment in 1976. Levine et al. (1996) traced the history and impact of Medicaid restrictions, reminding us that the law prevents the use of federal Medicaid funds to pay for most abortions and allows states to impose similar funding restrictions. After a long legal battle challenging the constitutionality of the amendment, in 1980 the Supreme Court ruled in Harris $v \mathrm{McRae}^{9}$ and Williams $v \mathrm{Zbaraz}^{10}$ that the restriction was constitutional. This resulted in the majority of states restricting the use of public funding for abortion, making the right to access often abstract for those who could not afford the procedure (Ross and Solinger 2017, p. 80).

Further challenges in the US also resulted in a serious modification of Roe introduced by the Planned Parenthood $v$ Casey ${ }^{11}$ case. As Siegel and Greenhouse highlight (Siegel and Greenhouse 2018), it is in fact Casey, not Roe, that currently shapes abortion access for US women. Casey, decided in 1992, upholds the central reasoning of Roe in terms of protecting privacy in personal choices such as the decision to undergo abortion. At the same time, however, it adds a stronger emphasis on the interest of the government in regulating abortion (Siegel 2008, p. 1749) as well as several conditions seriously impacting the understanding of women's rights:

It [Casey] adopted instead an "undue burden" standard that permitted the state to regulate abortion to protect unborn life from the beginning of pregnancy, so long as the state protected life by means that respected women's authority to decide whether to give birth. In so holding the Court created opportunities for opponents of abortion to enact restrictions on abortion that Roe itself never sanctioned, restrictions that were designed to transform the public's understandings of the morality and the constitutionality of the practice. (Siegel and Greenhouse 2018, p. 21)

This modification subsequently resulted in restrictions such as those introduced in the controversial HB2 Bill introduced by Texas in 2013, which rendered abortion practically inaccessible. Section 171.0031 of the Bill required a physician performing an abortion to have active admitting privileges at a hospital located no further than 30 miles away on the day of performing or inducing the abortion, as well as for the facility to meet regulatory standards for ambulatory surgical centers (Goodwin 2017, p. 95). As Goodwin demonstrated, this has translated to the existence of such areas as Rio Grande, from where there is only one eligible clinic within a 230-mile radius. This of course meant that women who could not afford abortion or afford to travel further were most impacted by the restrictions.

The legal ambivalence in terms of securing the right to abortion was also re-emphasized when it comes to Ireland in the case A. B. and C. $v$ Ireland ${ }^{12}$ before the ECtHR in 2010. Rather than securing the right to privacy or following the COE's earlier recommendations encouraging Member States to decriminalize abortion, the Court ruled in favor of tradition and the morality of the Irish community (Gozdecka 2015a). While deciding whether Article 8 was compliant with the prevention of abortion for reasons of health and well-being, the ECtHR put strong emphasis on the role of the "profound

\footnotetext{
Gonzales v. Carhart 550 U.S. 124. 2007.

Harris v McRae 448 U.S. 297. 1980.

Williams v. Zbaraz, 448 U.S. 358 (1980).

1 Planned Parenthood of Southeastern Pennsylvania v. Casey 505 U.S. 833. 1991.

12 A, B and C v Ireland. 2010. App No 25579/05. Strasbourg: European Court of Human Rights.
} 
moral views of the majority of the Irish people" (A.B and C v Ireland 2010, p. 126) in limiting access to abortion. It found that limitations of access dictated by the protection of the moral views of the majority constituted a legitimate aim in a democratic society (Gozdecka 2015a) and did not violate some of the applicants' right to privacy entrenched in the Convention.

As shown in this section, full recognition of women's reproductive rights, including access to abortion, has never been legally settled in either of these countries. This volatile situation has had a particular effect on poorer women, for whom access to public funding or even clinics have been key issues preventing them from accessing abortion. Ross and Solinger have compellingly illustrated that reproductive injustice has particularly touched poor women, who have often been treated as undeserving of public support for their reproductive rights and been excluded from considerations when discussing abortion access restrictions (Ross and Solinger 2017, p. 80). As Aiken notes, laws restricting Roe have had damaging and cumulative effects on those who lack financial and social resources (Aiken 2019, p. 1). Borchelt further illustrated that the need of raising money is a crucial problem in access to abortion for many:

Women struggling to make ends meet who are denied abortion coverage and are also forced to confront additional costs imposed by abortion restrictions are left with few options. They may have to postpone paying for other basic needs like food, rent, heating, and utilities to save the money for an abortion. In one study, more than one-third of women who had an abortion in the second trimester stated that they would have preferred to have the procedure earlier but could not because they needed to raise money. The greater the delay in obtaining an abortion, the more expensive the procedure becomes, catching poor women in a vicious cycle. (Borchelt 2018, p. 6)

The examples of Ireland and the United States show that even Western democracies that otherwise seem to be leaders on an international human rights stage have historically struggled with the recognition of women's rights to make autonomous decisions regarding the 'spacing and number of their children'. This has been particularly strongly visible in cases concerning access to abortion. Slow gains in abortion access have been fought-for for decades, while continuous challenges to these legal gains have created multiple legal barriers preventing women from accessing abortion. Despite the perceived commitment to rights, the examples of Ireland and the United States show that women's access to reproductive rights has hardly been legally set in stone. Thus, the perception of a backlash as a simple abandonment of progress oversimplifies the years of struggles which women have been experiencing in those countries.

\section{Beyond the Abortion Debate: Current Legal Challenges to Women's Reproductive Rights}

The election of Donald Trump as President of the United States resulted in increased anxiety over access to reproductive rights not only in the United States but globally. In the same year as Trump's election, the Supreme Court decided the case of Whole Woman's Health $v$ Hellerstedt ${ }^{13}$. While Whole Woman's Health found the laws restricting admitting (HB2) to be overly restrictive and the ambulatory requirements to be excessive, it did not use the opportunity to strengthen the guarantees of access to abortion. Goodwin sees the victory in Whole Woman's Health as only partial, highlighting that:

Despite the meaningful victory represented in Whole Woman's Health v Hellerstedt, the Court evaluated only two questions related to the legislation and did not address the broader plethora of laws described above, that prevail against women in states like Missouri, Mississippi, North Dakota, South Dakota, and Wyoming where only one abortion clinic remains. Indeed, it would be a mistake to read Whole Woman's Health as representing a fundamental change to abortion access on the ground level, because the conditions in many states continue to so significantly burden and stigmatize that right, particularly for poor women. (Goodwin 2017, p. 104)

13 Whole Woman's Health v. Hellerstedt 579 U.S. 2016. 
Soon after the election, the Trump administration introduced a number of other measures seen as restrictive to women's reproductive rights globally. First, Trump imposed the so-called 'global gag rule' with the power of his executive order, circumventing the ordinary Congressional procedures. The policy, introduced by the executive order, prevented NGOs from receiving federal funding if they provided abortion counselling or referral services. The passing of the global gag rule has been seen as a direct threat to women's reproductive rights specific to Trump's times (Bingenheimer and Skuster 2017). Yet the policy, similarly to the challenges in Roe, is but a reiteration of multiple earlier attacks on funding for reproductive rights. As Ruth Macklin reminds us, the policy is merely a reiteration of an old Republican policy from 1984 called the Mexico City Policy:

The original name for this policy derives from the announcement made by the administration of former President Ronald Reagan at the United Nations International Conference on Population, in 1984 in Mexico City. In its initial formulation, the policy required non-governmental organisations (NGOs) outside the US to certify that they will not "perform or actively promote abortion as a method of family planning" with funds from any donor, including their own money, as a condition for receiving US global family planning assistance. (Macklin 2019, p. 198)

Macklin further notes that every Republican government since has followed the policy and every democratic government has annulled it thereafter, suggesting the unfinished and ever-ongoing struggle for reproductive rights in the US rather than the simple reversal implied in the notion of "backlash." Trump's reiteration of the policy is a part of this ongoing struggle for women's rights and its main impact is a widening of the gap in access to reproductive justice globally, impacting women in the poorest countries the most (Macklin 2019). The International Women's Health Coalition published a report Crisis in Care: Two Year Impact of Trump's Global Gag Rule (International Women's Health Coalition 2019) illustrating how the policy has impacted the poorest women in places such as Nepal, Kenya or Nigeria and how it resulted in decreased quality of care for the most marginalized (International Women's Health Coalition 2019, pp. 21-24).

At the end of 2018, Trump's administration also published new rules that allowed the denial of contraceptive coverage to employees for religious reasons, giving politicized religious arguments a strong legal victory. As Chuang and Weisman observed, this once again widened the gap between poor and wealthy women (Chuang and Weisman 2019, p. 994). This gap had existed prior to Trump's draft, with just 29 states having coverage, and only 11 providing full coverage (Chuang and Weisman 2019, p. 993). This led to the disparity in contraceptive care and reproductive justice that had already been significant in the US prior to the current conservative government (Hammond 2019). While these developments certainly impact already spotty contraceptive coverage and broaden existing barriers to the goals of the reproductive rights movement, they are not a novelty but a result of a weak commitment to women's reproductive rights more generally. Rohlinger and Grace (2018) observe that the battle for women's reproductive rights has been ongoing for years on several grounds: within administrations, courts, communities, and clinics. The current challenges are certainly no sign of progress and they most severely impact those needing access to reproductive rights the most.

Meanwhile, in Ireland, the situation seems to have diametrically shifted as a result of the 2018 Popular Referendum in favour of the Annulment of the 8th Amendment. The result of the referendum was seen as a promise and the culmination of years of fighting against restrictive abortion laws. As Fletcher puts it:

(... ) repeal would see us reclaim our very constitution, in law, in body, and in territory, as we asked others to vote with us. Repeal made the impossible possible as moments of conversation, together with their silent pauses, at kitchen tables, information stalls, street platforms and media studios, assembled somehow and turned a deceptively simple 'yes' out of a mess of collective joy, heart-breaking stories, legal exchange and reproductive connections. (Fletcher 2018, p. 254)

However, as others observed, while the vote itself victoriously culminated years of women's struggle, it did not automatically mean fair access to abortion for all. Kasstan (2018) noted that the 
projected legal amendments replacing the ban include options such as the conscience clauses for physicians, allowing for the refusal of abortion for conscientiously objecting doctors and resulting in similar access issues as in the US. Both from the point of view of conscientious objectors (Donnelly and Murray 2020) and women seeking abortion, inclusion of such clauses is highly complex and has a potential to deepen the gap in reproductive justice:

It is likely that refusal on the part of GPS to comply with professional obligations will be more pronounced in rural, isolated, and close-knit communities in Ireland, which could force women to migrate internally for access to abortion care. Women in such areas may also feel unable to access abortion-related consultations from their GPs due to perceived shame or lack of confidentiality. (Kasstan 2018, p. 52)

The current backlash is an exploitation of the already weak commitment to women's reproductive rights globally. While a handful of countries have enjoyed significant progress since the adoption of CEDAW and the Cairo and Beijing Platforms for Action, others have witnessed the return of an agenda promoting traditional gender roles and restricting women's reproductive choices, as a result of the lack of common reproductive rights standards. With the resurgence of politicized traditionalist religions and the strengthening representation within conservative political movements, the exploitation of vague, uncertain, and weak legal commitment is slowly becoming more pronounced and the gap between aspirations and legal reality more and more significant. This begins to be visible in places previously thought of as progressive and friendly to women's rights. Franklin illustrated how, for instance, the Brexit narrative had reinstated the defense of white national sovereignty, traditional family values, and conventional gender roles (Franklin 2019) and how the same narratives have been seen in Germany and other countries utilizing anti-immigration rhetoric, resulting in the pressure on "native" white women to reproduce (Franklin and Ginsburg 2019, pp. 5-6). Countries where nationalistic parties have been ruling and re-elected, such as Poland, have intensified their efforts to limit women's access to abortion (Szelewa 2016), contraception (Król and Pustułka 2018), assisted reproduction (Gozdecka 2012) and recently even sexual education (Douglas 2019).

In other words, the twenty-first century has hardly seen the strengthening of the goals of CEDAW, or the Cairo or Beijing Platforms for Action. Quite the contrary, the fragile progress of the 1970s to 1990s has been slowly but steadily eroded in some of the countries that have seen objections to the idea of reproductive rights in the first place. The steady exploitation of legal loopholes allowing for the control of women's bodily autonomy and the return of nationalistic and traditionalist narratives defining women's reproductive roles have been negatively impacting women's abilities to decide on the 'number and spacing of their children'. This effect, as illustrated here, has widened the gap between legal aspirations and legal reality, as well as the gap in reproductive justice. In the end, the current backlash leaves those most vulnerable even worse off, and those who would benefit most from access to reproductive health services in even greater need of them.

\section{Conclusions}

As illustrated, women's reproductive freedoms have always been subject to their fragile position among the broader rights catalogue. Despite their inclusion in CEDAW, their legal position has always oscillated between soft law, temporary legal gains, and subsequent challenges and setbacks. While the perception of "backlash" is not entirely unfounded, this backlash should be understood in a nuanced way-namely as the strengthened ability of narratives of politicized religion and the reproduction of nationhood to impact access to reproductive rights negatively-rather than as a radical departure from legal standards set in stone. These narratives signify no improvement to women's bodily autonomy and have been actively mounting legal challenges to reproductive freedoms for decades. The return of these narratives signifies the potential broadening of barriers in access to reproductive rights, which are most likely to affect poorer women and women from otherwise marginalized backgrounds. Women have struggled with reproductive rights constraints across the globe, with smaller or greater success, 
and have faced multiple challenges in that area, both before and after the adoption of reproductive rights in human rights law. While wealthier women will continue to access these services in a worst case scenario by continuing to contribute to reproductive tourism, poor and marginalized women will be left at the mercy of the only accessible abortion clinic, or the availability of a doctor who recognizes the freedom of reproductive choice. The backlash against women's reproductive rights in the twenty-first century thus moves us further from the goal of achieving universal reproductive justice.

Funding: This research received no external funding.

Conflicts of Interest: The authors declare no conflict of interest.

\section{References}

Ahdar, Rex J. 2017. Worlds Colliding: Conservative Christians and the Law. Abingdon upon Thames: Routledge. Aiken, Abigail R. A. 2019. Erosion of women's reproductive rights in the United States. BMJ 366: 1-2. [CrossRef] Al-Hibri, Azizah Y. 1999. Is western patriarchal feminism good for third world/minority women? In Is Multiculturalism Bad for Women? Edited by Susan Moller Okin. Princeton: Princeton University Press.

Andaya, Elise. 2019. I'm building a wall around my uterus: Abortion Politics and the Politics of Othering in Trump's America. Cultural Anthropology 34: 10-17. [CrossRef]

Bano, Samia. 2016. In the name of God? Religion and feminist legal theory. In The Ashgate Research Companion to Feminist Legal Theory. Abingdon upon Thames: Routledge, pp. 169-86.

Bingenheimer, Jeffrey B., and Patty Skuster. 2017. The foreseeable harms of Trump's global gag rule. Studies in Family Planning 48: 279-90. [CrossRef] [PubMed]

Borchelt, Gretchen. 2018. The Impact Poverty Has on Women's Health. Human Rights Chicago 43: 16-18.

Borgmann, Caitlin E. 2008. The meaning of life: Belief and reason in the abortion debate. Columbia Journal of Gender and Law 18: 551-608.

Caron, Simone M. 2008. Who Chooses?: American Reproductive History Since 1830. Florida: University Press of Florida.

Convention on the Elimination of All Forms of Discrimination Against Women, United Nations General Assembly. 1979. Treaty Series; New York: United Nations, December 18, vol. 1249.

Chrisler, Joan C. 2014. A reproductive justice approach to women's health. Analyses of Social Issues and Public Policy 14: 205-9. [CrossRef]

Chuang, Cynthia H., and Carol S. Weisman. 2019. Taking Aim at Contraceptive Coverage-The Trump Administration's Attacks on Reproductive Rights. The New England Journal of Medicine 380: 993-95. [CrossRef]

Cottingham, Jane, Eszter Kismodi, Adriane Martin Hilber, Ornella Lincetto, Marcus Stahlhofer, and Sofia Gruskin. 2010. Using human rights for sexual and reproductive health: Improving legal and regulatory frameworks. Bulletin of the World Health Organization 88: 551-55. [CrossRef]

Cumberland, Sarah. 2012. From population control to human rights. World Health Organization. Bulletin of the World Health Organization 90: 86-87.

De Londras, Fiona, and Mairead Enright. 2018. Repealing the 8th. Bristol: Policy Press.

Donnelly, Mary, and Claire Murray. 2020. Abortion care in Ireland: Developing legal and ethical frameworks for conscientious provision. International Journal of Gynecology \& Obstetrics 148: 127-32.

Douglas, Elliot. 2019. Poland: New Legislation Treats Sex Education as ‘Pedophilia', Deutche Welle. October 16. Available online: https://www.dw.com/en/poland-new-legislation-treats-sex-education-as-pedophilia/a50853031 (accessed on 11 February 2020).

Ehrlich, J. Shoshanna, and Alesha E. Doan. 2019. Abortion Regret: The New Attack on Reproductive Freedom. Santa Barbara: ABC-CLIO.

Elomäki, Anna, and Johanna Kantola. 2018. Theorizing feminist struggles in the triangle of neoliberalism, conservatism, and nationalism. Social Politics: International Studies in Gender State E Society 25: 337-60.

European Parliament. 2002. Committee on Women's Rights and Equal Opportunities. Report on Sexual and Reproductive Health and Rights (2001/2128 (INI). Brussels: European Parliament, June 6.

European Parliament. 2009. Situation of Fundamental Rights in the European Union 2004-2008. Resolution 2007 (2145) (INI). Brussels: European Parliament, January 14. 
Fineman, Martha L. A. 1995. Masking dependency: The political role of family rhetoric. Virginia Law Review 81: 2181-216. [CrossRef]

Fletcher, Ruth. 2018. Repealed The 8th: Translating Travesty, Global Conversation, and the Irish Abortion Referendum. Feminist Legal Studies 26: 233-59. [CrossRef]

Franklin, Sarah. 2019. Nostalgic Nationalism: How a Discourse of Sacrificial Reproduction Helped Fuel Brexit Britain. Cultural Anthropology 34: 41-52. [CrossRef]

Franklin, Sarah, and Faye Ginsburg. 2019. Reproductive politics in the age of trump and Brexit. Cultural Anthropology 34: 3-9. [CrossRef]

Freedman, Lynn P., and Stephen L. Isaacs. 1993. Human rights and reproductive choice. Studies in Family Planning 24: 18-30. [CrossRef]

Friedland, Roger. 2001. Religious nationalism and the problem of collective representation. Annual Review of Sociology 27: 125-52. [CrossRef]

Gibson, Katie L. 2008. The rhetoric of Roe v. Wade: When the (male) doctor knows best. Southern Communication Journal 73: 312-31. [CrossRef]

Ginsburg, Ruth Bader. 1985. Some thoughts on autonomy and equality in relation to Roe v. Wade. North Carolina Law Review 63: 375-86.

Goodwin, Michele. 2017. Troubling Legislative Agendas: Leveraging Women's Health against Women's Reproductive Rights. Advance: The Journal of the ACS Issue Briefs 11: 93-106.

Gozdecka, Dorota Anna. 2009. Moral obligations of the state or a woman's right to privacy. NoFo: Journal of Extreme Legal Positivism 6: 89-99.

Gozdecka, Dorota Anna. 2012. The Polish Catholic Church and the regulation of IVF in Poland: Polarised political discourses and the battle over 'proper'reproduction. Feminists Law 2.

Gozdecka, Dorota Anna. 2015a. A community of paradigm subjects? Rights as corrective tools in culturally contested claims of recognition in Europe. Social Identities 21: 328-44. [CrossRef]

Gozdecka, Dorota Anna. 2015b. Rights, Religious Pluralism and the Recognition of Difference: Off the Scales of Justice. Abingdon upon Thames: Routledge.

Greenhouse, Linda. 2009. Democracy and the courts: The case of abortion. Hastings Law Journal 61: $1333-44$.

Greenhouse, Linda, and Reva B. Siegel. 2011. Before (and after) Roe v. Wade: New questions about backlash. The Yale Law Journal 120: 2028-87.

Hammond, Alexandra. 2019. Disparities in Access to Contraception in the United States: An Intersectional Analysis. Claremont College Thesis, Scripps Senior Theses. 1356. Claremont College, Claremont, CA, USA.

Himmelstein, Jerome L. 1986. The social basis of antifeminism: Religious networks and culture. Journal for the Scientific Study of Religion 25: 1-15. [CrossRef]

Hooton, Angela. 2005. A broader vision of the reproductive rights movement: Fusing mainstream and Latina feminism. American University Journal of Gender, Social Policy E the Law 13: 59-86.

International Women's Health Coalition. 2019. Crisis in Care: Two Year Impact of Trump's Global Gag Rule. Available online: https://31u5ac2nrwj6247cya153vw9-wpengine.netdna-ssl.com/wp-content/uploads/2019/ 06/IWHC_GGR_Report_2019-WEB_single_pg-2.pdf (accessed on 20 February 2020).

Kasstan, Ben. 2018. Irish voters repealed the eighth: now it's time to ensure access to abortion care in law and in practice. Reproductive Health Matters 26: 51-53. [CrossRef] [PubMed]

Król, Agnieszka, and Paula Pustułka. 2018. Women on strike: Mobilizing against reproductive injustice in Poland. International Feminist Journal of Politics 20: 366-84. [CrossRef]

Labbok, Miriam H., Paige Hall Smith, and Emily C. Taylor. 2008. Breastfeeding and feminism: A focus on reproductive health, rights and justice. International Breastfeeding Journal 3: 1-6. [CrossRef]

Levine, Phillip B., Amy B. Trainor, and David J. Zimmerman. 1996. The effect of Medicaid abortion funding restrictions on abortions, pregnancies and births. Journal of Health Economics 15: 555-78. [CrossRef]

Lottes, Ilsa L. 2002. Sexual health policies in other industrialized countries: Are there lessons for the United States? Journal of Sex Research 39: 79-83. [CrossRef] [PubMed]

Macklin, Ruth. 2019. The "Global gag rule": Curtailing women's reproductive rights. Indian Journal of Medical Ethics 4: 198-201. [CrossRef] [PubMed]

Malloy, Jonathan. 2017. Political opportunity structures, evangelical Christians and morality politics in Canada, Australia and New Zealand. Australian Journal of Political Science 52: 402-18. [CrossRef] 
Mijatovic, Dunja. 2019. We Need to Stand up for Women's Sexual and Reproductive Health and Rights. Saint Strasbourg: Council of Europe Commissioner for Human Rights. Available online: https://www.coe.int/en/web/ commissioner/-/we-need-to-stand-up-for-women-s-sexual-and-reproductive-health-and-rights (accessed on 11 February 2020).

Mohr, James C. 1979. Abortion in America: The Origins and Evolution of National Policy. Oxford: Oxford University Press.

Morgan, Lynn M. 2019. Reproductive Governance, Redux. Medical Anthropology 38: 113-17. [CrossRef] [PubMed] Okin, Susan Moller. 1999. Is Multiculturalism Bad for Women? Princeton: Princeton University Press.

Parliamentary Assembly of the Council of Europe. 2004a. European Strategy for the Promotion of Sexual and Reproductive Health and Rights. Recommendation 1675.2004. Strasbourg: Council of Europe, October 5.

Parliamentary Assembly of the Council of Europe. 2004b. European Strategy for the Promotion of Sexual and Reproductive Health and Rights. Resolution 1399. Strasbourg: Council of Europe, October 5.

Parliamentary Assembly of the Council of Europe. 2008a. Access to Safe and Legal Abortion. Report. Doc. 11537 rev. Strasbourg: Council of Europe, April 8.

Parliamentary Assembly of the Council of Europe. 2008b. Access to Safe and Legal Abortion in Europe. Resolution 1607. 2008. Strasbourg: Council of Europe, April 16.

Peters, Julie Stone, and Andrea Wolper, eds. 2018. Women's Rights, Human Rights: International Feminist Perspectives. Abingdon upon Thames: Routledge.

Pohlman, Harold L. 2005. Constitutional Debate in Action: Civil Rights and Liberties. Lanham: Rowman \& Littlefield Publishers.

Reichenbach, Laura, and Mindy Roseman, eds. 2011. Reproductive Health and Human Rights: The Way Forward. Pennsylvania: University of Pennsylvania Press.

Riddle, Jennifer. 2002. Making CEDAW universal: Critique of CEDAW's reservation regime under article 28 and the effectiveness of the reporting process. George Washington International Law Review 34: 605-38.

Roberts, Dorothy. 2015. Reproductive justice, not just rights. Dissent 62: 79-82. [CrossRef]

Rohlinger, Deana A., and Jessie Grace. 2018. Nevertheless, They Persisted: Feminisms and Continued Resistance in the US Women's Movement. Abingdon upon Thames: Routledge.

Rohlinger, Deana, and David S. Meyer. 2005. Transnational Framing of Access to Abortion in the United States, England, and Ireland. In The US Women's Movement in a Global Perspective. Edited by Leonard Banaszak. Lanham: Rowman \& Littlefield Publishers, pp. 197-214.

Rose, Melody. 2011. Pro-life, pro-woman? Frame extension in the American antiabortion movement. Journal of Women Politics \& Policy 32: 1-27.

Ross, Loretta, and Rickie Solinger. 2017. Reproductive Justice: An introduction. Berkeley: University of California Press, vol. 1.

Siegel, Rickie. 2007. Sex equality arguments for reproductive rights: Their critical basis and evolving constitutional expression. Emory Law Journal 56: 815-42.

Siegel, Reva. 2008. Dignity and the politics of protection: Abortion restrictions under Casey/Carhart. Yale Law Journal 117: 1694-801. [CrossRef]

Siegel, Reva, and Linda Greenhouse. 2018. The Unfinished Story of Roe V. Wade. In Reproductive Rights and Justice Stories. Edited by Melissa Murray, Kate Shaw and Reva Siegel. St. Paul. Foundation Press.

Small, Andrew. 2018. From conflict to consensus: Reconciling the right to freedom of religion and LGBT rights. Alternative Law Journal 43: 221-24. [CrossRef]

Smith, Andrea. 2005. Beyond pro-choice versus pro-life: Women of color and reproductive justice. NWSA Journal 17: 119-40. [CrossRef]

Smyth, Lisa. 2002. Feminism and abortion politics: Choice, rights, and reproductive freedom. Women's Studies International Forum 25: 335-45. [CrossRef]

Starrs, Ann M. 2017. The Trump global gag rule: An attack on US family planning and global health aid. The Lancet 389: 485-86. [CrossRef]

Stearns, Nancy. 1988. Roe v. Wade: Our struggle continues. Berkeley Women's Law Journal 4: 1-11.

Szelewa, Dorota. 2016. Killing 'unborn children'? The Catholic church and abortion law in Poland since 1989. Social \& Legal Studies 25: 741-64.

United Nations. 1995. Beijing Declaration and Platform of Action, Adopted at the Fourth World Conference on Women. New York: United Nations, October 27. 
Wald, Kenneth D., Dennis E. Owen, and Samuel S. Hill. 1988. Churches as political communities. American Political Science Review 82: 531-48. [CrossRef]

Wald, Kenneth D., Adam L. Silverman, and Kevin S. Fridy. 2005. Making sense of religion in political life. Annual Review of Political Science 8: 121-43. [CrossRef]

Yuval-Davis, Nira. 1996. Women and the biological reproduction of "the nation". Women's Studies International Forum 19: 17-24. [CrossRef]

Ziegler, Mary. 2013. Roe's race: The supreme court, population control, and reproductive justice. Yale Journal of Law and Feminism 25: 1-50. [CrossRef]

Ziegler, Mary. 2014. Beyond backlash: Legal history, polarization, and Roe v. Wade. Washington and Lee Law Review 71: 969-1024.

Ziegler, Mary. 2015. After Roe. Harvard: Harvard University Press.

Ziegler, Mary. 2018. Beyond Abortion: Roe V. Wade and the Battle for Privacy. Harvard: Harvard University Press.

(C) 2020 by the author. Licensee MDPI, Basel, Switzerland. This article is an open access article distributed under the terms and conditions of the Creative Commons Attribution (CC BY) license (http://creativecommons.org/licenses/by/4.0/). 